DOI: 10.17707/AgricultForest.61.3.04

\author{
Dragutin ĐUKIĆ, Leka MANDIĆ, \\ Slavica VESKOVIĆ, Ivana KAPOR ${ }^{1}$
}

\title{
CORRELATION BETWEEN FERTILIZER TYPE AND RATE, UREASE ACTIVITY AND TOTAL NITROGEN AND AMMONIUM NITROGEN CONTENTS IN A CHERNOZEM SOIL UNDER WHEAT
}

\begin{abstract}
SUMMARY
Research was conducted on the effects of mineral fertilizers and manure on urease activity and total nitrogen and ammonium nitrogen contents, and their correlation in a chernozem soil during four developmental stages of wheat.

The study involved the following treatments: unfertilized control; N2 (100 $\mathrm{kg} / \mathrm{ha} \mathrm{N}$ ); P2 (100 kg/ha P); K2 (100 kg/ha K); N2P2; N2K2; P2K2; N1P1K1 (50:50:50 kg/ha); N2P2K2; N3P3K3 (150:150:150 kg/ha), and N1P1K1 + solid manure (20 t/ha). Urease activity was determined by the method of Hofmann, and total nitrogen and ammonium nitrogen by the Kjeldahl method.

The combined application of low NPK fertilizer rates and manure resulted in increased urease activity. All treatments with three-component mineral fertilizers, two-component P2K2 and phosphorus P2 applied during the first two phenophases of wheat inhibited the soil urease activity, whereas at other developmental stages their effect and the effect of other mineral fertilizers on the activity of the enzyme were non-significant. The results indicate differing effects of mineral fertilizers on total $\mathrm{N}$ in the soil regardless of developmental stages. Of the single-component fertilizers, the highest total $\mathrm{N}$ level was recorded under $\mathrm{K}$ treatment. The use of two-component fertilizers produced a higher total $\mathrm{N}$ content compared to the single-component ones. Of the NPK treatments, total N content was highest under N2P2K2 treatment throughout the growing season. The N1P1K1 + manure treatment gave the highest amount of total N. Significant differences were found in ammonium $\mathrm{N}$ levels between the control and most of the other treatments during the growing season, but no definite pattern could be established.

There were no correlations either between the mineral fertilizers used and urease activity or between urease activity and total nitrogen and ammonium nitrogen contents.

Key words: soil, mineral fertilizers, manure, urease activity, total nitrogen, ammonium nitrogen

\footnotetext{
1 Dragutin Đukić, Leka Mandić, (corresponding author: lekamg@tfc.kg.ac.rs), University of Kragujevac, Faculty of Agronomy, Cara Dušana 34, 32000 Čačak, SERBIA, Slavica Vesković, Institute for Meat Hygiene and Technology, Kaćanskog 13, 11000 Belgrade, SERBIA, Ivana Kapor, University of East Sarajevo, Faculty of Agriculture, Vuka Karadzica 30, 71123 Republic of Srpska, BOSNIA AND HERZEGOVINA.

Note: The authors declare that they have no conflicts of interest. Authorship Form signed online.
} 


\section{INTRODUCTION}

The enzyme urease (3.5.1.5.) belongs to the group of hydrolytic enzymes and is characterized by the specific activity - it hydrolyzes only urea, without affecting its products. The optimum $\mathrm{pH}$ of urease is near 7.0, although its activity in the soil may take place within a rather wide $\mathrm{pH}$ range. The urease activity is calculated by means of the determination of ammonia formed during urea decomposition.

Urease activity in the soil is dependent on soil type, environmental conditions and cultural practices. In this regard, special importance is given to the type, rate and combination of fertilizers as the pillar of effective soil fertility. Zakarauskaite et al. (2008) found that low rates of NPK mineral fertilizers have no significant effect on urease activity, in contrast to high rates, particularly of $\mathrm{P}$ and $\mathrm{K}$, which lead to a significant reduction in the activity of the enzyme in cambisols. However, Leinweber et al. (2008) reported that low NPK fertilizer rates $\left(60 \mathrm{~kg} \mathrm{ha}^{-1}\right)$, during the first month after treatment, increase urease activity up to 35 days following application, with their stimulating effect fading away thereafter. Moreover, the use of organic substrates (solid manure, sewage sludge etc.) commonly stimulates the soil enzymatic activity (Crecchio et al., 2001; Madejon et al., 2001; Balezentiene and Klimas, 2009). High urease activity may also lead to certain adverse effects due to ammonia volatilization or denitrification losses, particularly in slightly alkaline and overly irrigated soils (Zaman et al., 2008; Gioacchini et al. 2002; Parfitt et al. 2006). This fact must be considered when determining the application rates and types of fertilizers for different types of soils and under specified agroenvironmental conditions.

Apart from urease activity, the amount of available nitrogen assimilates is also governed by the activity of other soil enzymes, such as proteolytic enzymes. The intensity and direction of these processes are also affected by soil and anthropogenic factors. Fertilization systems play an important role in this process as well. Narrowing the $\mathrm{C}: \mathrm{N}$ ratio through the separate or combined incorporation of nitrogenous fertilizers and well-rotted manure accelerates mineralization, thus favorably affecting the soil proteolytic activity and, hence, the amount of available nitrogenous compounds (Kaur et al., 2005; Chu et al., 2007).

These facts justify the assertion that soil enzymatic activity can be used as an important criterion in assessing the quality and productivity of soils (Yao et al., 2006).

The objective of this study was to evaluate the effect of different types and application rates of fertilizers on urease activity, total nitrogen and ammonium nitrogen in a chernozem soil, as well as their correlations during the wheat growing season.

\section{MATERIAL AND METHODS}

The experiment was conducted in Rimski Šančevi (latitude $45^{\circ} 45^{\prime} \mathrm{N}$; longitude $19^{\circ} 51^{\prime} \mathrm{E}$; altitude $84 \mathrm{~m}$ a.s.l.), Republic of Serbia, on a chernozem soil $\left(\mathrm{pH}_{\mathrm{KCl}} 7.02,2.5 \%\right.$ humus, $\left.0.14 \% \mathrm{~N}, 0.16 \mathrm{mg} / \mathrm{g} \mathrm{P}_{2} \mathrm{O}_{5}, 0.22 \mathrm{mg} / \mathrm{g} \mathrm{K}_{2} \mathrm{O}\right)$ in a 
randomized block design with four replications and plot size $12 \mathrm{~m}^{2}(4 \times 3 \mathrm{~m})$. Winter wheat cultivar 'Evropa 90' was used as the test plant. The following fertilization treatments (factor A) were employed: N2 (100 kg/ha N); P2 (100 $\mathrm{kg} / \mathrm{ha} \mathrm{P})$; K2 (100 kg/ha K); N2P2; N2K2; P2K2; N1P1K1 (50:50:50 kg/ha); N2P2K2; N3P3K3 (150:150:150 kg/ha), and N1P1K1 + solid manure (20 t/ha). Nitrogenous, phosphorus and potassium mineral fertilizers were applied as urea, superphosphate and $\mathrm{KCl}$, respectively. The total phosphorus and potassium fertilizer amounts and $1 / 3$ of nitrogenous fertilizer were used prior to seeding in autumn, and the remaining $2 / 3$ of the nitrogenous fertilizer as a soil dressing in March at the tillering stage. Solid manure (dry matter - 17.4\%, organic matter $13.3 \%$, nitrogen $-0.37 \%$, phosphorus $-0.23 \%$, potassium $-0.48 \%$ ) was plowed under in autumn 10 days before seeding. Soil samples for the analysis of urease activity, total nitrogen and ammonium nitrogen were taken aseptically down to a depth of $25 \mathrm{~cm}$ in four phenophases of wheat (factor B): I period - full stem elongation; II period - beginning of flowering; III period - milk stage; IV period full maturity.

The amount and distribution of rainfall and soil temperatures during the growing season are presented in Table 1.

Table 1. Amount and distribution of rainfall $(\mathrm{mm})$ and temperatures of soil $\left({ }^{\circ} \mathrm{C}\right)$ during the growing season of wheat

\begin{tabular}{|l|l|l|l|l|}
\hline \multirow{2}{*}{ Month } & \multicolumn{2}{|c|}{ Mean monthly temperatures of soil $(\mathrm{C})$} & \multirow{2}{*}{ Rainfall $(\mathrm{mm})$} \\
\cline { 2 - 4 } & $2 \mathrm{~cm}$ & $10 \mathrm{~cm}$ & $30 \mathrm{~cm}$ & \\
\hline IV & 12.1 & 11.5 & 10.6 & 26 \\
\hline V & 21.5 & 19.4 & 17.2 & 24 \\
\hline VI & 26.2 & 24.3 & 22.9 & 90 \\
\hline VII & 22.6 & 21.6 & 20.9 & 67 \\
\hline
\end{tabular}

Soil urease activity was assayed by the method of Hofmann (Hofmann, 1963) and expressed in $\mathrm{mg} \mathrm{NH}_{3}$ per $1 \mathrm{~g}$ of soil for 24 hours $\left(1 \mathrm{ml} 0.1 \mathrm{n} \mathrm{H}_{2} \mathrm{SO}_{4}\right.$ corresponds to $1.7 \mathrm{mg} \mathrm{NH}_{3}$ ). Total nitrogen and ammonium nitrogen were determined by the Kjeldahl method.

The results were subjected to a two-factor analysis of variance (fertilization, wheat phenophase), and the significance of differences was computed by the Lsd test, using SPSS software (StatSoft.Inc, 1995). The correlation between fertilizer application rates, urease activity and total nitrogen and ammonium nitrogen contents was expressed by the simple correlation coefficient.

\section{RESULTS AND DISCUSSION}

The analysis of variance showed a significant effect of fertilizers on soil urease activity, total nitrogen and ammonium nitrogen contents during the growing season of wheat. Their effect was found to depend on the type, rate and combination of fertilizers, as well as on wheat phenophase. 
The highest increase in urease activity compared to the control was under the combined application of low NPK fertilizers rates and manure, particularly at initial developmental stages of wheat. At the end of the growing season (full maturity), the effect was non-significant (Table 2). The results are in agreement with the findings of Plaza et al. (2004) and Kaur et al. (2005) who stressed the importance of separate or combined applications of manure and low mineral fertilizer rates in increasing the numbers of soil microorganisms i.e. their enzymatic activity. In this research, during the first two phenophases, all threecomponent mineral fertilizers, two-component fertilizers (P2K2) and the single application of phosphorus (P2) resulted in reduced urease activity in the soil. During the other wheat phenophases, their effect was non-significant, as was the effect of the other types, rates and combinations of mineral fertilizers throughout the growing season. The results of the research conducted over several years by Zakarauskaite et al. (2008) also suggest that low rates of mineral fertilizers have no significant effect on urease activity, whereas application rates above 150 $\mathrm{kg} / \mathrm{ha}$ significantly reduce the activity of the enzyme in cambisols. Yao et al. (2006) and Balezentiene and Klimas (2009) observed that the decline in urease activity during the wheat growing season may be due to lowered mineralization substrate availability and increased soil temperature.

Table 2. Urease activity ( $\mathrm{mg} \mathrm{NH}_{3} / \mathrm{g}$ soil per 24 hours) in chernozem during the four phenophases of wheat (I - full stem elongation; II - beginning of flowering; III - milk stage; IV - full maturity) depending on the applied fertilizers

\begin{tabular}{|l|l|l|l|l|}
\hline \multirow{2}{*}{ Fertilization (A) } & \multicolumn{4}{|c|}{ Phenophase (B) } \\
\cline { 2 - 5 } & I & II & III & IV \\
\hline Without fertilization & $0.361 \mathrm{c}$ & $0.282 \mathrm{cde}$ & $0.215 \mathrm{e}-\mathrm{j}$ & $0.193 \mathrm{~g}-\mathrm{k}$ \\
\hline N2* & $0.346 \mathrm{~cd}$ & $0.223 \mathrm{e}-\mathrm{h}$ & $0.204 \mathrm{e}-\mathrm{k}$ & $0.177 \mathrm{~g}-\mathrm{k}$ \\
\hline P2 & $0.278 \mathrm{def}$ & $0.194 \mathrm{~g}-\mathrm{k}$ & $0.153 \mathrm{~h}-\mathrm{k}$ & $0.164 \mathrm{~g}-\mathrm{k}$ \\
\hline K2 & $0.346 \mathrm{~cd}$ & $0.215 \mathrm{e}-\mathrm{j}$ & $0.176 \mathrm{~g}-\mathrm{k}$ & $0.175 \mathrm{~g}-\mathrm{k}$ \\
\hline N2P2 & $0.334 \mathrm{~cd}$ & $0.202 \mathrm{e}-\mathrm{k}$ & $0.170 \mathrm{~g}-\mathrm{k}$ & $0.166 \mathrm{~g}-\mathrm{k}$ \\
\hline N2K2 & $0.340 \mathrm{~cd}$ & $0.214 \mathrm{e}-\mathrm{j}$ & $0.175 \mathrm{~g}-\mathrm{k}$ & $0.170 \mathrm{~g}-\mathrm{k}$ \\
\hline P2K2 & $0.198 \mathrm{f}-\mathrm{k}$ & $0.153 \mathrm{~h}-\mathrm{k}$ & $0.130 \mathrm{k}$ & $0.136 \mathrm{jk}$ \\
\hline N1P1K1 & $0.244 \mathrm{efk}$ & $0.175 \mathrm{~g}-\mathrm{k}$ & $0.147 \mathrm{~h}-\mathrm{k}$ & $0.158 \mathrm{~h}-\mathrm{k}$ \\
\hline N2K2P2 & $0.218 \mathrm{e}-\mathrm{j}$ & $0,154 \mathrm{~h}-\mathrm{k}$ & $0.141 \mathrm{ijk}$ & $0.153 \mathrm{~h}-\mathrm{k}$ \\
\hline N3P3K3 & $0.204 \mathrm{e}-\mathrm{k}$ & $0,144 \mathrm{~h}-\mathrm{k}$ & $0.136 \mathrm{jk}$ & $0.147 \mathrm{~h}-\mathrm{k}$ \\
\hline N1P1K1 + manure & $1.130 \mathrm{a}$ & $0,511 \mathrm{~b}$ & $0.342 \mathrm{~cd}$ & $0.204 \mathrm{e}-\mathrm{k}$ \\
\hline
\end{tabular}

*N2-100 kg/ha N; P2-100 kg/ha P; K2-100 kg/ha K; N1P1K1-50:50:50 kg/ha; N3P3K3150:150:150 kg/ha, solid manure-20 t/ha.

Values followed by different small letters within the table are significantly different $(\mathrm{P} \leq 0.05)$ according to the LSD test; 
The results obtained (Table 3 ) indicate a more or less opposite effect of mineral fertilizers in relation to the total $\mathrm{N}$ in the soil, which was in agreement with the results of Stanojković (2010). Regardless of developmental stages, of the single fertilizers applied, the highest total $\mathrm{N}$ level was recorded in the variant with potassium. The variants with two-component fertilizers produced a higher total $\mathrm{N}$ content compared to the one-component ones. The highest $\mathrm{N}$ content was obtained with the variant $\mathrm{N} 2 \mathrm{P} 2$, which is in agreement with the results of Polesko (1970). Of NPK variants, total $\mathrm{N}$ content was highest with the variant N2P2K2 throughout the vegetation period. However, the introduction of manure (N1P1K1 + manure) increased the total $\mathrm{N}$ content throughout the vegetation, so that this variant produced the highest amount of total nitrogen, as confirmed by the results of other authors (Kaur et al., 2005; Chu et al., 2007).

The tendency for the increase in the total $\mathrm{N}$ during the vegetation of wheat can be supported by the fact that the plants grown on chernozem secrete larger amounts of organic matter at the phase of heading (in small grains) and that root parts die out (Jakovljević, 1979).

Table 3. Content of total nitrogen ( $\mathrm{mg} \mathrm{N} / \mathrm{kg}$ soil) in chernozem during the four phenophases of wheat (I - full stem elongation; II - beginning of flowering; III milk stage; IV - full maturity) depending on the applied fertilizers

\begin{tabular}{|l|l|l|l|l|}
\hline \multirow{2}{*}{ Fertilization (A) } & \multicolumn{4}{|c|}{ Phenophase (B) } \\
\cline { 2 - 5 } & I & II & III & IV \\
\hline Without fertilization & $1314 \mathrm{r}$ & $1325 \mathrm{qr}$ & $1344 \mathrm{pqr}$ & $1379 \mathrm{op}$ \\
\hline N2* & $1358 \mathrm{pq}$ & $1365 \mathrm{pq}$ & $1435 \mathrm{n}$ & $1451 \mathrm{mn}$ \\
\hline P2 & $1339 \mathrm{pqr}$ & $1360 \mathrm{pq}$ & $1414 \mathrm{no}$ & $1449 \mathrm{mn}$ \\
\hline K2 & $1484 \mathrm{~lm}$ & $1433 \mathrm{n}$ & $1442 \mathrm{n}$ & $1454 \mathrm{mn}$ \\
\hline N2P2 & $1587 \mathrm{e}-\mathrm{h}$ & $1591 \mathrm{~d}-\mathrm{g}$ & $1594 \mathrm{def}$ & $1681 \mathrm{a}$ \\
\hline N2K2 & $1505 \mathrm{kl}$ & $1517 \mathrm{jkl}$ & $1533 \mathrm{jk}$ & $1538 \mathrm{jjk}$ \\
\hline P2K2 & $1517 \mathrm{jkl}$ & $1531 \mathrm{jk}$ & $1535 \mathrm{jjk}$ & $1540 \mathrm{jjk}$ \\
\hline N1P1K1 & $1533 \mathrm{jk}$ & $1552 \mathrm{~g}-\mathrm{j}$ & $1549 \mathrm{hi}$ & $1582 \mathrm{fgh}$ \\
\hline N2K2P2 & $1631 \mathrm{bcd}$ & $1596 \mathrm{def}$ & $1626 \mathrm{~b}-\mathrm{e}$ & $1664 \mathrm{abc}$ \\
\hline N3P3K3 & $1556 \mathrm{f}-\mathrm{i}$ & $1575 \mathrm{f}-\mathrm{i}$ & $1589 \mathrm{efg}$ & $1591 \mathrm{~d}-\mathrm{g}$ \\
\hline N1P1K1 + manure & $1654 \mathrm{abc}$ & $1624 \mathrm{cde}$ & $1659 \mathrm{abc}$ & $1666 \mathrm{ab}$ \\
\hline
\end{tabular}

*N2-100 kg/ha N; P2-100 kg/ha P; K2-100 kg/ha K; N1P1K1-50:50:50 kg/ha; N3P3K3150:150:150 kg/ha, solid manure-20 t/ha.

Values followed by different small letters within the table are significantly different $(\mathrm{P} \leq 0.05)$ according to the LSD test;

Under N2, P2, medium (N2P2K2) and high rates (N3P3K3) of the threecomponent fertilizers and the combined treatment with mineral and organic fertilizers, ammonium nitrogen levels significantly decreased at all phenophases, except the first one, compared to the same phenophases in the control (Table 4). Such variability in the value of this form of nitrogen may be associated with its 
conversion into nitrate or other nitrogenous forms, as well as with partial volatilization, particularly in fertilized treatments under increased soil temperature and moisture conditions, as confirmed by other authors (Kaur et al., 2005; Zaman et al., 2008). Generally, the highest levels of ammonium nitrogen, in single-component mineral fertilization treatments, were recorded for the $\mathrm{N} 2$ treatment and, except in the first period, they were significantly higher than for P2 and K2 treatments which resulted in approximately the same amount of this form of nitrogen throughout the growing season. Except the third phenophase under N2P2 treatment, the amounts of ammonium nitrogen following twocomponent fertilizer applications were also similar. As for the three-component fertilizers, the amount of ammonium nitrogen was the highest under N3P3K3 treatment and combined N1P1K1 + manure treatment. In the other two combinations of three-component fertilizers, ammonium nitrogen levels were approximately the same throughout the growing season.

A correlation was found to exist between the content of ammonium nitrogen and the application rate of NPK during the vegetation of wheat, which is in agreement with the results of Stanojkovic, (2010).

Table 4. Content of $\mathrm{N}^{-\mathrm{NH}_{4}}\left(\mathrm{mg} \mathrm{N}-\mathrm{NH}_{4} / \mathrm{kg}\right.$ soil) in chernozem during the four phenophases of wheat (I - full stem elongation; II - beginning of flowering; III milk stage; IV - full maturity) depending on the applied fertilizers

\begin{tabular}{|l|l|l|l|l|}
\hline \multirow{2}{*}{ Fertilization (A) } & \multicolumn{4}{|c|}{ Phenophase (B) } \\
\cline { 2 - 5 } & I & II & III & IV \\
\hline Without fertilization & $6.42 \mathrm{fgh}$ & $10.5 \mathrm{abc}$ & $9.92 \mathrm{bcd}$ & $11.25 \mathrm{ab}$ \\
\hline N2* & $5.80 \mathrm{ghi}$ & $7.00 \mathrm{fg}$ & $8.75 \mathrm{de}$ & $7.00 \mathrm{fg}$ \\
\hline P2 & $5.25 \mathrm{~h}-\mathrm{k}$ & $4.08 \mathrm{kl}$ & $5.25 \mathrm{~h}-\mathrm{k}$ & $5.25 \mathrm{~h}-\mathrm{k}$ \\
\hline K2 & $5.25 \mathrm{~h}-\mathrm{k}$ & 3.501 & $5.83 \mathrm{ghi}$ & $5.25 \mathrm{~h}-\mathrm{k}$ \\
\hline N2P2 & $4.08 \mathrm{kl}$ & 3.501 & $9.33 \mathrm{~cd}$ & $5.25 \mathrm{~h}-\mathrm{k}$ \\
\hline N2K2 & 3.501 & 3.501 & $5.60 \mathrm{hij}$ & $4.08 \mathrm{kl}$ \\
\hline P2K2 & 3.501 & 3.501 & $6.30 \mathrm{fgh}$ & $5.25 \mathrm{~h}-\mathrm{k}$ \\
\hline N1P1K1 & $4.66 \mathrm{ijk}$ & $5.25 \mathrm{~h}-\mathrm{k}$ & $6.42 \mathrm{fgh}$ & 3.501 \\
\hline N2K2P2 & $7.58 \mathrm{ef}$ & $5.25 \mathrm{~h}-\mathrm{k}$ & $6.65 \mathrm{fgh}$ & $4.20 \mathrm{jkl}$ \\
\hline N3P3K3 & $6.42 \mathrm{fgh}$ & $9.30 \mathrm{~cd}$ & $11.50 \mathrm{a}$ & 3.501 \\
\hline N1P1K1 + manure & $8.75 \mathrm{de}$ & $7.58 \mathrm{ef}$ & $8.75 \mathrm{de}$ & $5.25 \mathrm{~h}-\mathrm{k}$ \\
\hline
\end{tabular}

*N2-100 kg/ha N; P2-100 kg/ha P; K2-100 kg/ha K; N1P1K1-50:50:50 kg/ha; N3P3K3150:150:150 kg/ha, solid manure-20 t/ha.

Values followed by different small letters within the table are significantly different $(\mathrm{P} \leq 0.05)$ according to the LSD test;

On the basis of the results obtained (Table 5) it can be concluded that there is no correlation either between the mineral fertilizers applied and the activity of ureases, or between urease and total and ammonium nitrogen. 


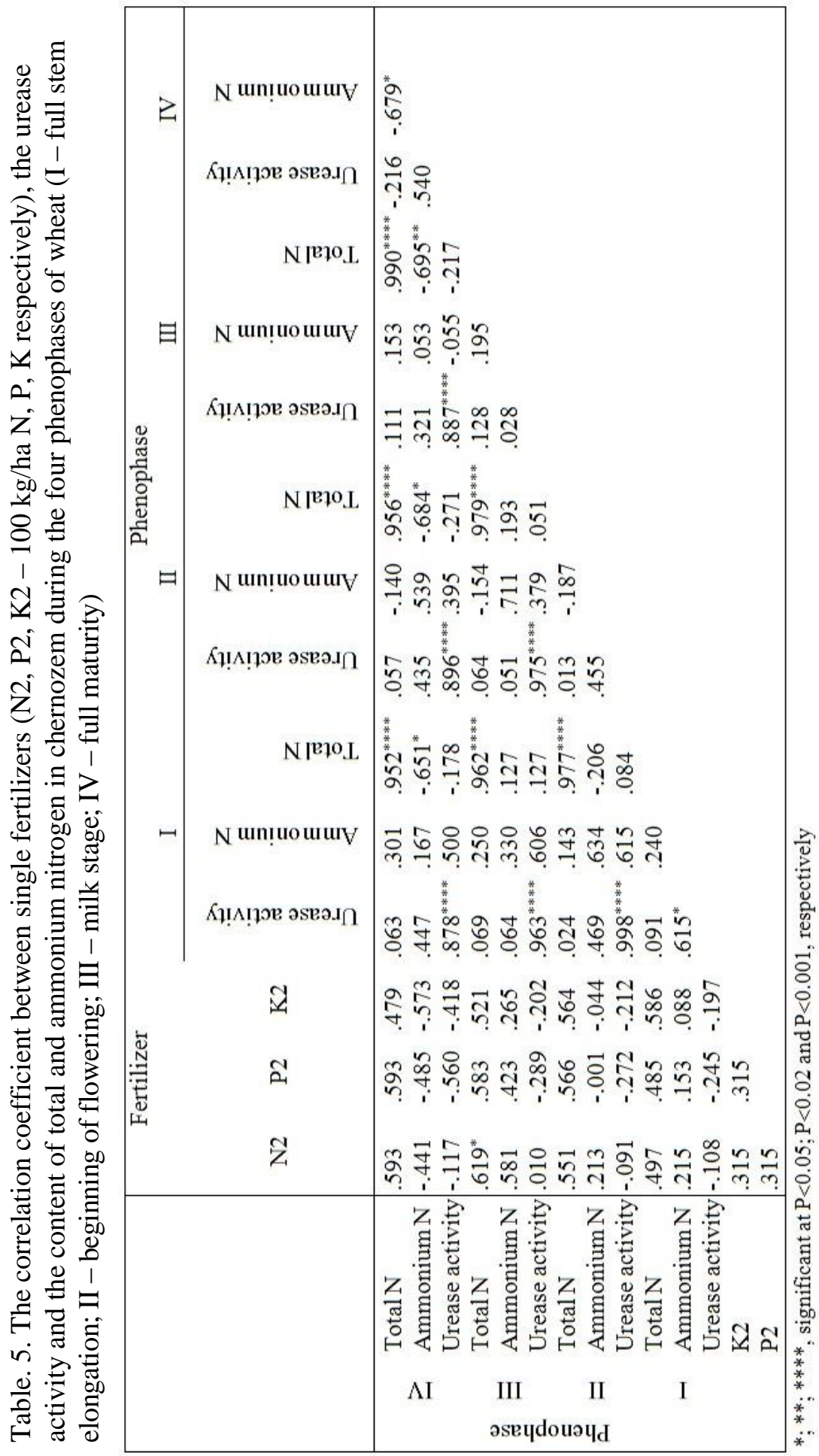




\section{CONCLUSIONS}

The fertilizers used had a significant effect on urease activity and total nitrogen and ammonium nitrogen contents in the soil during the growing season of wheat. Their effect differed, depending on cultivar, fertilizer rates and combinations, and wheat phenophase. The combined application of low NPK fertilizer rates and manure resulted in increased urease activity. During the first two phenophases, all three-component mineral fertilizers, two-component fertilizers (P2K2) and the single application of phosphorus (P2) inhibited the soil urease activity, whereas at other phenophases their effect and the effect of the other mineral fertilizers on the activity of the enzyme was non-significant. All fertilizers led to a significant increase in total nitrogen content in the soil, particularly under $\mathrm{N} 2 \mathrm{P} 2 \mathrm{~K} 2$ and combined $\mathrm{N} 1 \mathrm{P} 1 \mathrm{~K} 1$ + solid manure treatment. Of the two-component fertilizers, N2P2 gave the highest total nitrogen content. Under N2, P2, medium and high rates of the three-component fertilizers (N2P2K2 and N3P3K3, respectively) and the combined treatment with mineral and organic fertilizers, ammonium nitrogen levels significantly decreased at all phenophases, except the first one, compared to the control. No positive correlation was observed between the fertilizers applied and urease activity, nor between urease activity and total nitrogen and ammonium nitrogen contents in the soil.

\section{ACKNOWLEDGEMENTS}

This study is part of the project "Improvement of the genetic potential of forage crops and production technologies towards the sustainable development of animal husbandry" - TR 31057 funded by the Ministry of Education and Science, Republic of Serbia

\section{REFERENCES}

Balezentiene, L. \& Klimas, E. (2009): Effect of organic and mineral fertilizers and land management on soil enzyme activities. Agronomy Research, 7(Special issue I): 191-197.

Chu, H., Lin, X., Fujii, T., Morimoto, S., Yagi, K., Hu, J., Zhang, J. (2007): Soil microbial biomass, dehydrogenase activity, bacterial community structure in response to long-term fertilizer management. Soil Biology \& Biochemistry, 39: 2971-2976.

Crecchio, C., Curci, M., Mininni, R., Ricciuti, P., Ruggiero, P. (2001): Short term effects of municipal solid waste compost amendments on soil carbon and nitrogen content, some enzyme activities and genetic diversity. Biology and Fertility of Soils 34: 311-318.

Gioacchini, P, Nastri, A, Marzadori, C. (2002): Influence of urease and nitrification inhibitors on $\mathrm{N}$ losses from soils fertilized with urea. Biol. Fertil. Soils, 36: 129135.

Hofmann, E. (1963): Urease. In H.U. Bergmeyer, eds, Methods of Enzymatic Analysis, pp. 913-946. New York, Academic, USA.

Jakovljević, M. (1979): Proučavanje mehanizma aktiviranja azota zemljišta pod uticajem azota iz dodatog đubriva. Arhiv za poljoprivredne nauke, 32(120): 41-82. 
Kaur, K., Kapoor, K.K., Gupta, A.P. (2005): Impact of organic manures with and without mineral fertilizers on soil chemical and biological properties under tropical conditions. Journal of Plant Nutrition and Soil Science 168: 117-122.

Leinweber, P., Jandl, G., Baum, C., Eckhardt, K., Kandeler, E. (2008): Stability and composition of soil organic matter control respiration and soil enzyme activities. Soil Biology \& Biochemistry, 40: 1496-1505.

Madejon, E., Burgos, P., Lopez, R., Cabrera, F. (2001): Soil enzymatic response to addition of heavy metals with organic residues. Biology and Fertility of Soils, 34: 144- 150 .

Parfitt, R.L., Schipper, L.A., Baisden, W.T., Elliott, A.H. (2006): Nitrogen inputs and out puts for New Zealand in 2001 at national and regional scales. Biogeochemistry, 80: 71-88.

Plaza, C., Hernandez, D., Garcia-Gil, J.C., Polo, A. (2004): Microbial activity in pig slurry-amended soils under semiarid conditions. Soil Biology \& Biochemistry 36: $1577-1585$.

Polesko, Y.A. (1970): Vlijanie mineralnih udobrenii na mobilizaciju azota v pochve i ispolzovnie ego rasteniyami. Pochvovedenie, 11: 69-73.

Stanojković, A. (2010): Biološka produktivnost gajnjače u uslovima primene mineralnih i mikrobioloških đubriva pod višegodišnjim plodoredom žitarica. Agronomski fakultet u Čačku (Doktorska disertacija).

StatSoft.Inc. (1995): Statistica for Windows (computer program manual). Tulsa. OK: StatSoft.Inc.

Yao, X.H., Huang, M., Lu, Z.H., Yuan, H.P. (2006): Influence of acetamiprid on soil enzymatic activities and respiration. European J. Soil Biol. 42: 120-126.

Zakarauskaite, D., Vaišvila, Z., Motuzas, A., Grigaliūnienè, K., Buivydaite, V.V., Vaisvalavičius, R., Butkus, V. (2008): The influence of long-term application of mineral fertilizers on the biological activity of Cambisols. Ekologija, 54(3): 173178.

Zaman, M., Nguyen, M.L., Blennerhassett, J.D., Quin B.F. (2008): Reducing NH3,N2O and NO3-N losses from a pasture soil with urease or nitrification inhibitors and elemental S-amended nitrogenous fertilizers. Biol. Fertil. Soils, 44: 693-705 